and the people in charge of the village dispensaries, from whom the kind of person to organize and lead discussions after a film show or broadcast might be recruited.

With the help of higher educational institutions, of teachers' training colleges and, in the case of Nigeria, of the National Union of Teachers, a special course might be started on discussion group techniques and the use of visual aids. To this course could come both certificated and uncertificated teachers. A simpler course could be run for volunteers who may not be teachers but who are willing and able to act as discussion group leaders in their own localities. Official help is needed for the training of projectionists.

Once a nucleus of people is trained in using films or broadcasts as a stimulus to discussion, on their return to their particular community or village they could attempt to pass on what they have learned to additional small groups, later advising the filmmakers and educators of their experiences.

\section{FORESTRY IN NIGERIA AND THE GOLD COAST}

\section{ANNUAL REPORTS FOR THE YEAR 1948-49}

$\mathrm{T}$ HE reports of the Forest Departments of Nigeria* and of the Gold Coast $†$ both mention some progress made in forest management during the year 1948-49. The Nigerian report states that there has been a surge of development in Nigeria as a whole, from the commercial, administrative and political points of view, and this has to some extent overshadowed forestry progress. It is stated that the dispersal of experienced men at all levels, which is the inevitable consequence of rapid expansion of staff, has not been the least of the problems. It is difficult to understand what is meant by this, since Nigeria has for so long been notorious for the shortness of forestry staff compared with the size of the country and the size of the areas to be put under a much more intense management. From the experience gained at universities in Great Britain, Nigeria would appear to have been somewhat hasty in the initiation of higher training for African officer staff at the new University College at Ibadan.

As to the strength of the gazetted staff, it is now fifty-six, having risen from forty-five, and this is not a very great increase for such a big important forestry country, since the staff was at least fifty in 1934 . There is no doubt that the liaison between members of the House of Assembly and the Department of Forestry should be all to the good.

The forestry policy of the whole of the country, especially of the northern region, is badly in arrears. The concentration of the staff where the revenue can be made has not been in the interest of the northern populations, which probably require the attentions of the forester quite as much as the more revenueproducing areas. This neglect of the north is one reason for the very low numbers of the executive staff which have been maintained for so long in the

* Nigeria. Annual Report on the Forest Administration of Nigeria for the Year 1948-49. Pp. 59. (Lagos: Government Printer ; London: Crown Agents for the Colonies, 1950.)

$\uparrow$ Gold Coast Colony. Report on the Forest Department for the Year 1948-49. Pp. 22. (Acera: Government Printing Department London: (rown Agents for the Colonies, 1949.) 28 .
Nigerian Forest Department, and yet it has just been learned in Great Britain that seven forestry appointments which were to have been made in Nigeria have been withdrawn at the instance, presumably, of the exigencies of finance. For rural planning and developments, so far as forestry and agriculture are concerned, a strong cadre of fully trained forest officers will prove indispensable.

In the introductory remarks to the report for the Gold Coast, it is stated that a new and detailed forest policy formulated in 1946 has now been formally approved by the Governor in Council. There is not very much new in these statements of policy that has not appeared over and over again in the reports and government statements for all of the Colonial Services in which there is a forest department; but in many of them it has not yet achieved a very wide success. More especially is this so in connexion with the aim so often enumerated of the forest policy: "management of permanent forest resources by methods that will achieve maximum productivity and value on the basis of a sustained yield". If backnumbers of various annual forestry reports are consulted, it becomes easily apparent that these Colonies are very far from having achieved this policy.

The Gold Coast report goes on to discuss the progress in the execution of the policy made. One important point in connexion with this introduction and maintenance of the sustained yield is disclosed by the statements that considerable progress has been made in stocktaking in forest reserves, but that there is still a considerable programme ahead. To the forester this at once discloses the position of the Colony and how far behind it is in this matter after thirty to forty years of a Forest Department.

A point of real interest is the native administration forestry under which native authorities are encouraged to manage and develop their forest reserves, and new rules give them opportunities to do so. As might have been expected from practices of the past, starting a century or so ago in India, little progress has been made by Native Authorities in the provision of land for fuel plantations. One of the reserves is being steadily developed as a demonstration area for this purpose. It is interesting to note that in the Northern Territories, which a few years ago were almost entirely neglected by the Forest Department, nine proposed reserves are to be made, and there will be some interesting forestry work undertaken in the future if the present policy in connexion with the Northern Territories is really given effect.

During the year an inter-Colonial conference in forestry and other questions was held in Accra under the chairmanship of the Chief Secretary of the West African Council. The first part of the conference discussed general forestry questions and was attended by Mr. W. A. Robertson, technical adviser to the Secretary of State in Forestry, and by the chief conservators of forestry of Nigeria, the Gold Coast and Sierra Leone. The second part discussed timber utilization and was attended by the general manager of the railways, representatives of the Public Works Department, and representatives of the timber trade, Nigeria and the Gold Coast.

It is apparent from this Gold Coast report that there is now much closer co-operation between forestry and the Departments of Agriculture, Animal Health and Customs. 